\title{
PEMETAAN INDUSTRI PENGOLAHAN PANGAN UNGGULAN BERBASIS SISTEM INFORMASI GEOGRAFIS PADA PROPINSI JAWA TENGAH
}

\author{
Teddy Oswari ${ }^{1}$, Fenni Agustina $^{2}$, Emy Haryatmi $^{3}$, E. Susy Suhendra ${ }^{4}$ \\ Fakultas Ekonomi, Universitas Gunadarma, Jakarta ${ }^{1,4)}$ \\ Fakultas Teknologi Industri, Universitas Gunadarma, Jakarta ${ }^{2,3)}$ \\ Jl. Margonda Raya 100, Depok, Jawa Barat \\ Email : toswari ${ }^{1}$, fenni ${ }^{2}$,emy_ $h^{3}$, susys ${ }^{4}$ [@staff.gunadarma.ac.id]
}

\begin{abstract}
The emphasis of the agricultural industry in Indonesia lies in the program of increasing food security, agribusiness development and improving the welfare of farmers. The priority of food security in establishing the independence of farmers in maintaining local resources efficiently and optimally, so that resources can be utilized further. The objectives of the research are to mapping the leading food processing industry, the determination of the leading local resources, the formation of documentation and the making of Geographic Information System (GIS) application to support the improvement of food processing industry in order to independence and food security, the growth and development of food industry in the region. The method of conducting research with data collection of food processing industry in Central Java Province by making data base and taxonomy, mapping of food processing industry in regency/city and making of digital portal with feature of data component of food processing industry to more introduce superior food processing industry to the public. The achieved results are documentation of leading food processing industry and GIS formation for all regencies/cities of Central Java Province, to encourage the improvement of food processing industry, real industrial income, processing quality and increasing self-sufficiency of food processing industry.
\end{abstract}

Keywords : Mapping, Industry, Processing, Superior Food.

\section{PENDAHULUAN}

Program unggulan lokal di Indonesia belum bisa terlepas sepenuhnya dari komoditi basis strategis. Hal ini tersurat pada rumusan pembangunan pertanian bahwa sasaran indikatif produksi komoditas utama tanaman pangan dan unggulan sampai tahun 2006. Namun demikian, semakin berkurangnya areal garapan per petani dan keterbatasan pasokan air irigasi dan mahalnya harga input serta relatif rendahnya harga produk dapat menjadi faktor - faktor pembatas dan kendala untuk program peningkatan kesejahteraan dan kemandirian petani yang berbasis sumber daya lokal tersebut (Badan Ketahanan Pangan Kementerian Pertanian Republik Indonesia, 2012).

Upaya menuju peningkatan kesejahteraan petani secara operasional akan dilakukan melalui pemberdayaan penyuluhan, pendampingan, penjaminan usaha, perlindungan harga, kebijakan proteksi dan promosi. Beberapa upaya tersebut memang relatif sangat diperlukan namun faktor kendala seperti disebutkan terdahulu perlu mendapatkan perhatian yang cermat hingga di tingkat daerah.

Grand strategi yang telah ditetapkan oleh Departemen Pertanian dalam pembangunan agribisnis yang pada intinya mencakup 4 hal penting, yaitu : (1) Pembangunan pertanian harus menjadi inti pembangunan nasional. (2) Pembangunan pertanian harus dilakukan melalui pendekatan sistem agribisnis.

Keberhasilan pembangunan agribisnis sebahagian besar tergantung pada faktor dan kebijaksanaan yang berada diluar jalur kewenangan Departemen Pertanian sehingga diperlukan upaya koordinasi yang sangat baik antar instansi terkait. (4) Pengembangan agribisnis harus mampu meningkatkan daya saing, membangun ekonomi kerakyatan, berkelanjutan dan terdesentralisasi dalam kerangka penguatan ekonomi daerah, sehingga pembangunan agribisnis dilakukan 
melalui pola - pola pembangunan potensi dan kapasitas ekonomi masyarakat.

Menurut Teddy dkk 2013, sistem informasi geografis sangat dibutuhkan dalam rangka mengatur keseimbangan produksi tanaman hortikultura di Jawa Barat dan berguna mendapatkan informasi yang akurat mengenai komposisi kebutuhan pasokan sayuran untuk komoditi tomat, kentang dan cabe merah di suatu daerah Kabupaten Bandung. Penelitian dan penerapan Sistem Informasi Geografis pada komoditas unggulan lokal di Indonesia saat ini sudah seharusnya menjadi basis data terhadap seluruh komoditas unggulan bagi para petani dan pebisnis agar dapat meningkatkan daya saing dan nilai jual eksport ke berbagai negara.

Pada kenyataannya program ketahanan pangan tersebut belum bisa terlepas dari pembangunan ketahanan pangan yang diarahkan untuk memenuhi kebutuhan pangan masyarakat yang cukup, bergizi, aman, bermutu sesuai selera dan keyakinannya, melalui peningkatan produktivitas, kualitas, dan efisiensi produksi pangan asal tanaman ternak dan ikan secara berkelanjutan; pengolahan hasil dan penganekaragaman pangan.

Permasalahan yang menjadi prioritas ketahanan pangan adalah pembentukan kemandirian petani dalam mempertahankan sumber daya lokal secara efisien dan optimal, sehingga sumber daya tersebut dapat dimanfaatkan lebih lanjut. Hal tersebut dapat tercapai dengan bantuan teknologi informasi dan komunikasi dengan pembentukan GIS (Geographic Information System) untuk menunjang terbentuk dan terjalinnya konsistensi ketahanan pangan di Indonesia pada umumnya (Teddy dkk, 2013).

Upaya untuk menuju pada peningkatan kesejahteraan petani secara operasional akan dilakukan melalui pemberdayaan penyuluhan, pendampingan, penjaminan usaha, perlindungan harga gabah, kebijakan proteksi dan promosi. Beberapa upaya tersebut memang relatif sangat diperlukan namun faktor kendala seperti disebutkan terdahulu perlu mendapatkan perhatian yang cermat hingga di tingkat daerah. Hal tersebut dapat dimengerti mengingat sebagian besar petani di Indonesia untuk komoditas pangan masih tergolong petani subsistem dalam artian berperan sebagai produsen sekaligus sebagai konsumen.

Berdasarkan hal tersebut maka faktor yang mendesak untuk dilakukan adalah mendokumentasikan dan memetakan hasil pertanian yang merupakan produk lokal unggulan. Pendokumentasian ini memerlukan pemanfaatan berbagai potensi fisik, ekonomi, lingkungan dan sosial budaya yang dimiliki. Salah satu potensi yang dapat dimanfaatkan untuk pendokumentasian dan pemetaan hasil pertanian di Indonesia adalah pemanfaatan teknologi informasi dan komunikasi. Pemanfaatan teknologi informasi dan komputer dalam pelestarian kebudayaan nasional dilakukan dengan mengembangkan dokumentasi sumber daya lokal dibidang pertanian, yang akan mendukung program ketahanan pangan dengan ketersediaan data yang terkini dengan tingkat kompleksitas yang tinggi, serta memiliki kemampuan accessbility dan relevancy informasi yang handal.

Adapun tujuan dari penelitian ini adalah melakukan pemetaan industri dalam menentukan sumber daya lokal yang menjadi andalan menggunakan jaringan Geographic Information System (GIS) untuk mendukung (1) merancang peningkatkan produksi pertanian melalui pembuatan prototype GIS guna melakukan pemetaan produk tanaman pangan unggulan lokal.

Permasalahan yang menjadi prioritas ketahanan pangan adalah pembentukan kemandirian petani dalam mempertahankan sumber daya lokal secara efisien dan optimal, sehingga sumber daya tersebut dapat dimanfaatkan lebih lanjut. Pemanfaatan sumber daya tersebut dilakukan dengan mengolah hasil pangan, sehingga dapat menghasilkan berbagai ragam produksi pangan dan menumbuhkan usaha pengolahan pangan baik rumah tangga, UMKM ataupun swasta. Hal tersebut dapat tercapai dengan bantuan teknologi informasi 
dan komunikasi dengan pembentukan GIS (Geographic Information System) untuk menunjang terbentuk dan terjalinnya konsistensi ketahanan pangan di Indonesia pada umumnya. Salah satu contoh industri pengolahan pangan di Jawa Barat adalah di kabupaten Garut tepatnya di desa Cilawu. Desa Cilawu merupakan salah satu tempat yang mengolah jagung menjadi emping dan brondong serta mengolah singkong menjadi kripik.

\section{METODE PENELITIAN}

Penelitian ini dilakukan menggunakan metode kualitatif dengan tahapan pengumpulan data pada industri pengolahan pangan Propinsi Jawa Tengah sebagai sampel penelitian. Sumber data berasal dari Kantor BKPM RI Pusat dan Dinas Koperasi dan UKM Jawa Tengah. Data diperoleh Tahun 2011 - 2014 berupa bidang usaha/industri pengolahan, lokasi industri, nilai investasi, produksi dan kapasitas. Selanjutnya dilakukan pembuatan basis data dan taksonomi pada industri pengolahan dan pemetaan disetiap kabupaten / kota dan pembuatan portal digital yang akan dilengkapi berbagai fitur basis data industri pengolahan pangan unggulan dengan sistem informasi geografis.

Operasionalisasi variabel Analisis sistem pada tahap survei pengumpulan data dan analisis terstruktur guna memperoleh pemahaman dari permasalahan, efisiensi dan pertimbangan yang mengarah ke pengembangan sistem. Analisis terstruktur menganalisis bahan masukan yang telah diperoleh dari hasil survai dengan analisis sistem dan prosedur, analisis sistem informasi, dan analisis sarana pendukung. Desain sistem konseptual dari hasil studi dan analisis yang dilakukan berdasarkan hasil desain konseptual, dengan model ataupun sub sistem yang telah didefinisikan.

Pemanfaatan hasil dari penelitian ini berupa basis data yang dihasilkan mengenai tanaman pangan dan taksonominya diharapkan dapat mengetahui kekhususan industri pengolahan pangan pada satu kabupaten, karenanya dapat mengurangi ketergantungan terhadap lokasi industri lainnya, basis data mengenai industri pengolahan pangan diharapkan dapat menjadi acuan keberadaan di satu kabupaten, portal industri pengolahan pangan virtual diharapkan dapat memenuhi kebutuhan tiap kabupaten untuk mencaritahu ciri khas industri dari kabupaten tersebut, peta GIS pada portal industri pengolahan pangan virtual diharapkan dapat menjadi acuan dan diharapkan dapat membantu investor untuk memperoleh informasi kemajuan industri pengolahan pangan.

\section{HASIL DAN PEMBAHASAN}

Menurut Z. Duran 2003, langkahlangkah perancangan pembuatan prototype web digitalisasi pengolahan pangan unggulan lokal berbasis Geographic Information System (GIS) adalah :

1. Melakukan instalasi tool pendukung MapServer, IDE / Text editor menggunakan notepat ++ atau tool yang lain, Database MySQL dan Instal Aplikasi Quantum GIS.

2. Melakukan penentuan wilayah pengamatan dan penelitian yaitu Pulau Jawa.

3. Penentuan data spasial dan non - spasial pada daerah tertentu di wilayah Jawa Tengah.

4. Melakukan tracking data spasial.

5. Pembuatan database.

6. Pembuatan web dan melakukan koneksi.

Prahasta, E. 2005, menyatakan Perancangan basis data dan taksonomi dilakukan dengan Model Data Hybrid. Langkah awal adalah pemahaman adanya dugaan mekanisme penyimpanan data yang optimal untuk informasi lokasi (data spasial atau koordinat - koordinat) di satu sisi, akan menyebabkan tidak optimalnya penyimpanan bagi informasi non - spasial di sisi yang lain. Maka, data kartografis (koordinat - koordinat) digital disimpan dalam sekumpulan file dengan sistem operasi direct acsess untuk meningkatkan kecepatan proses input-output, sementara itu, data 
atributnya akan disimpan di dalam format DBMS relasional standar.

Dengan demikian perangkat lunak SIG akan bertugas sebagai pengelola hubungan antara data spasial dan tabel - tabel atributnya yang berformat DBMS ini selama operasi - operasi pemrosesan atu analisis data peta berlangsung.

Sementara mekanisme yang dipakai untuk meggabungkan data spasial (layer) dengan tabel - tabel atributnya tetap sama, yaitu dengan mendefenisikan nomor pengenal (ID) sebagai atribut kunci yang unik pada unsur spasialnya dan kemudian menempatkannya pula didalam tabel atribut hingga memungkinkannya tetap saling terkait dalam usaha membentuk informasi yang utuh.

Model Data Terintegrasi. Pendekatan model data terintegrasi dapat dideskripsikan sebagai pendekatan sistem pengolahan basis data spasial, dengan SIG yang bertindak sebagai query processor. Kebanyakan implementasinya hingga sekarang ini adalah bentuk topologi vektor dengan tabel - tabel rasional yang menyimpan data koordinat kordinat unsur - unsur peta (titik, nodes, segmen garis, dan lain sebagainya) bersama dengan tabel - tabel lain yang berisi data topologi.

Dengan model data SIG yang terintegrasi (spasial - atribut), terdapat sejumlah karakteristik yang khusus pada data spasial sebagai implikasi dari penggunaanya.dari sudut pandang basis data, adalah memungkinkan untuk menyimpan baik data koordinat - koordinat maupun data mengenai topologi yang diperlukan untuk mengelompokkan elemen - elemen kartografis digital dengan menggunakan perancangan yang didasarkan pada bentuk normal Boyce Codd (Budiyanto, E., 2002).

Prahasta, E. 2007 menggambarkan story - board Web GIS yang telah dirancang, diawali dengan identifikasi kebutuhan prototype web seperti pada tampilan 1 terdapat penjelasan program hibah dalam pembuatan web ini dan adanya slide show gambar pertanian dan industri pengolahan pangan unggulan. Tampilan 2 memberikan informasi tentang isi web dan grafik komoditas unggulan, produksi masing masing daerah. Tampilan 3 khusus menjelaskan konten web GIS. Tampilan 4 menampilan e-book berbagai komoditas unggulan lokal yang juga dilengkapi dengan informasi produk dan gambar. Tampilan 5 menampilkan peta produk-produk daerah yang memiliki unggulan lokal. Tampilan 6 memberikan informasi tentang tim peneliti dan Tampilan 7 berisikan tabel - tabel kelengkapan konten web.

Berikut ini adalah tampilan design interface website Geographic Information System.

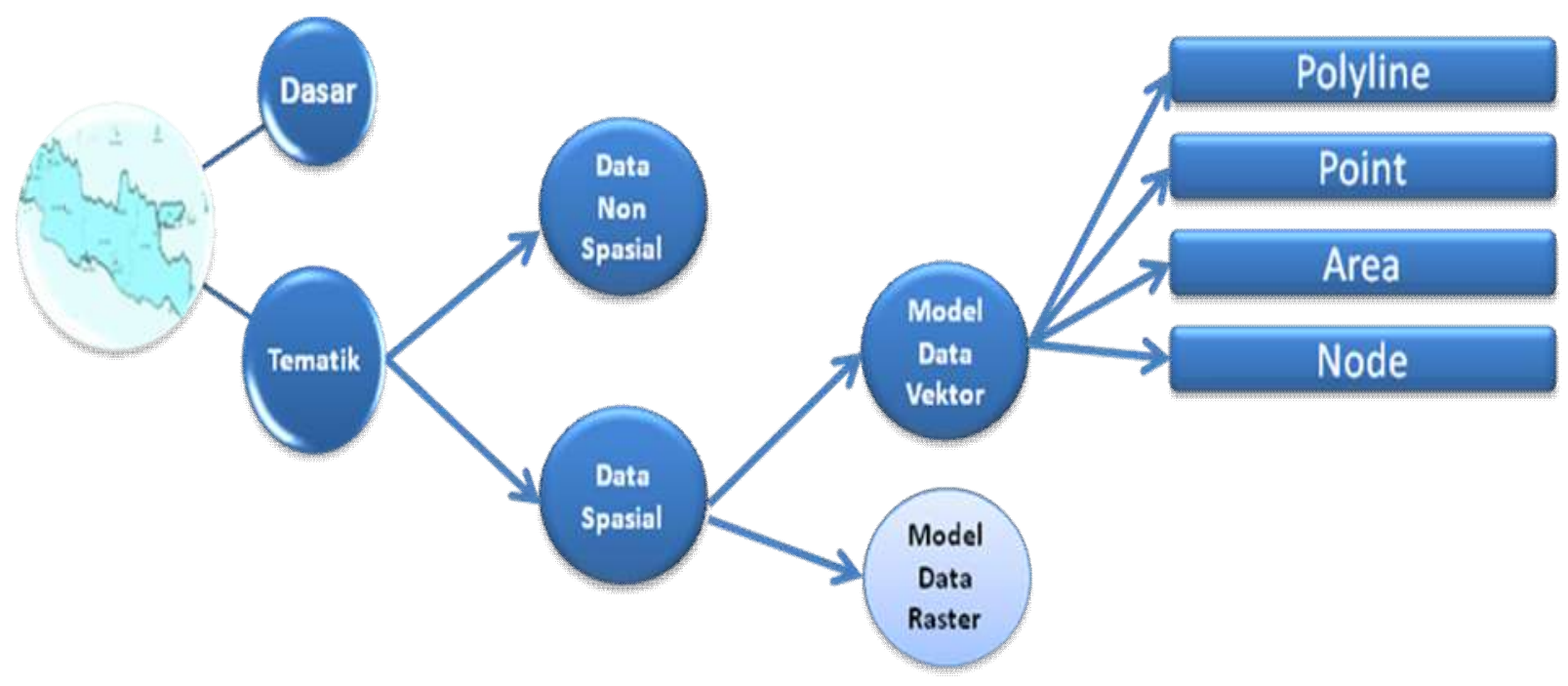

Gambar 1. Rancangan Sistem Informasi Geografis. 
Mao, J, R. dkk 2008, menyatakan prototype web Sistem Informasi Geografis sebaran industri makanan dan minuman di suatu daerah, ditujukan untuk pengguna yang ingin melihat hasil sebaran industri makanan dan minuman. Di Indonesia, sebaran industri makanan dan minuman yang ada di setiap propinsi dan kabupaten dapat diidentifikasi dengan baik. Prototype yang sudah dibuat saat ini merupakan prototype salah satu propinsi yang ada di Pulau Jawa, yaitu propinsi Jawa Tengah.

Tampilan halaman pertama web, setelah pengguna masuk ke hosting : www.risetindustripangan.com, maka akan muncul tampilan web, seperti pada gambar 2 . Pengguna dapat melihat pinpoint yang menunjukan nama propinsi Semarang dan nama Kabupaten yang ada di Kota Semarang. Pada web tersebut terdapat 2 tabel, yaitu Tabel Pilih Industri untuk Sortir dan Tabel Pilih Kota untuk Sortir.

Tampilan kedua pada gambar 3, kalau kita sorot / highlight tabel Pilih Industri untuk Sortir, maka akan memberikan informasi yang berisi pilihan 22 jenis industri makanan dan minuman yang dihasilkan.

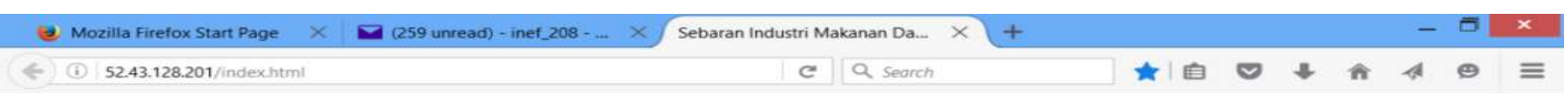

\section{SEBARAN INDUSTRI MAKANAN DAN MINUMAN DI INDONESIA}
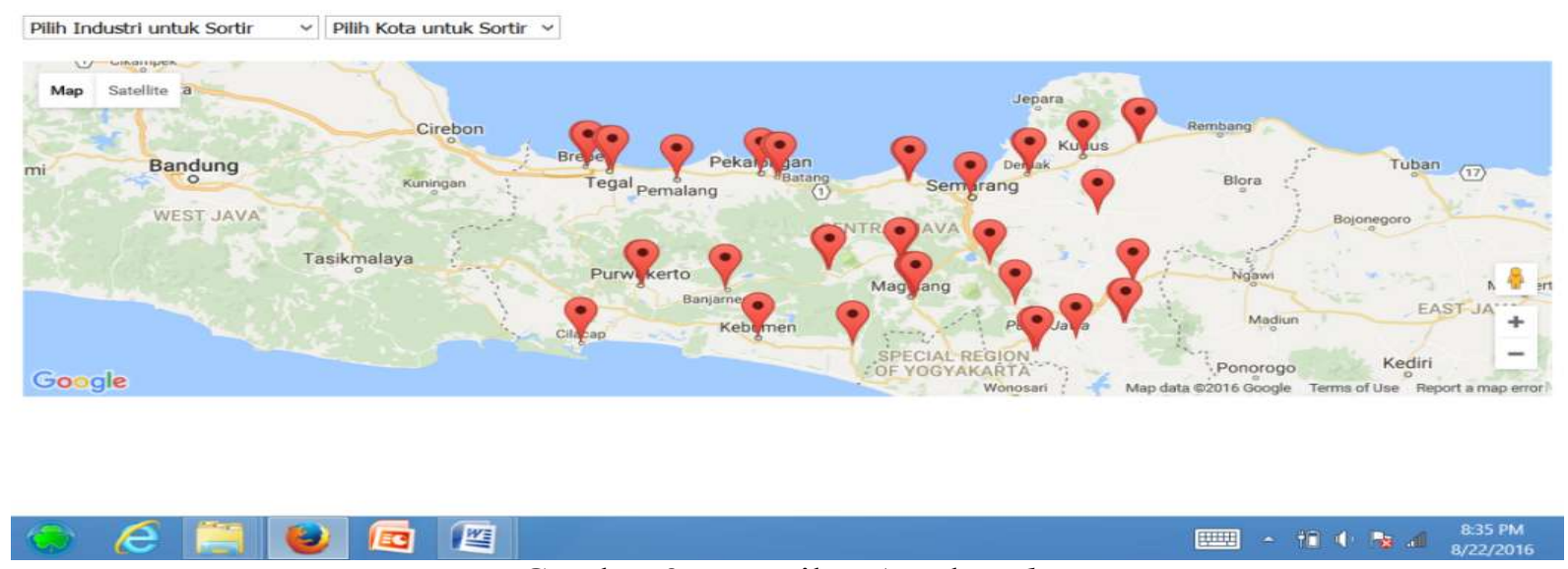

Gambar 2. Tampilan Awal Web.

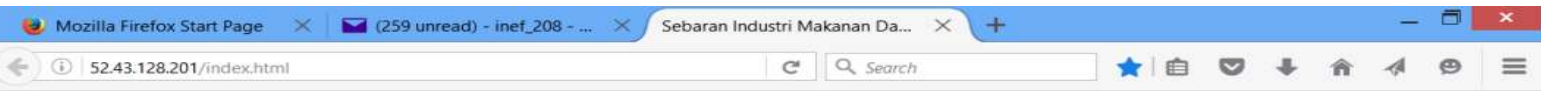

\section{SEBARAN INDUSTRI MAKANAN DAN MINUMAN DI INDONESIA}

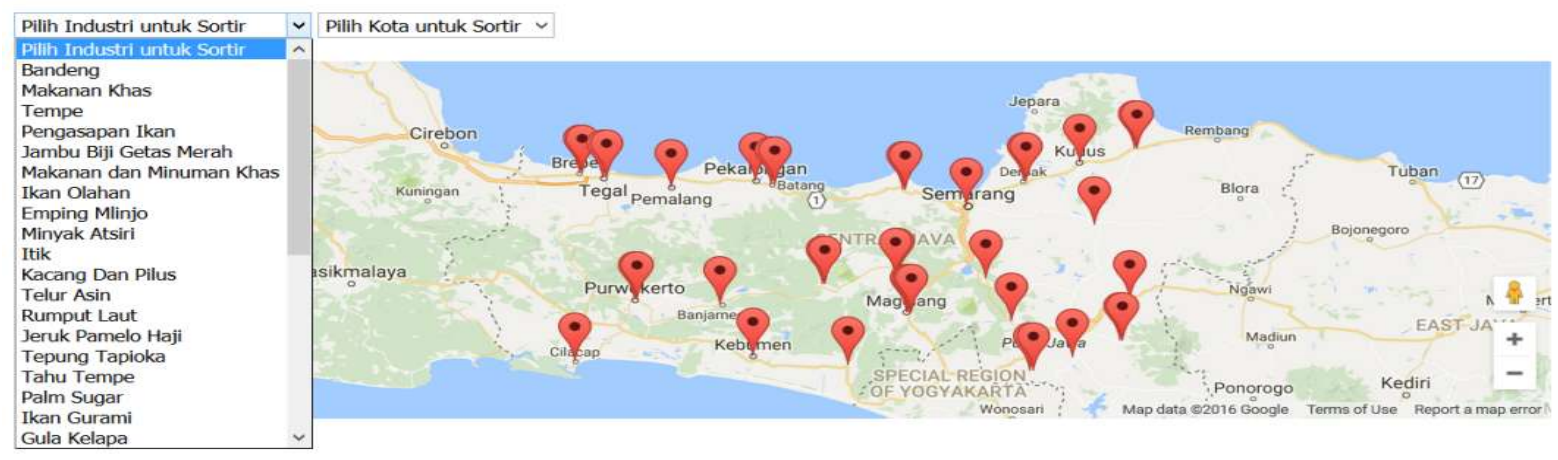

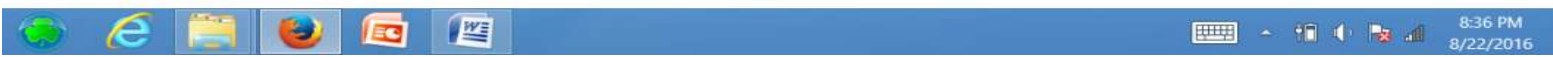

Gambar 3. Tampilan Informasi Pilih Industri untuk Sortir. 
Tampilan ketiga pada gambar 4, kalau kita sorot / highlight tabel Pilih Kota untuk Sortir yang berisi pilihan 25 nama kota Kabupaten yang ada di Propinsi Jawa Tengah.

Tampilan keempat pada gambar 5, apabila kita sorot / highlight salah satu jenis industri dan kotanya, maka akan muncul tampilan pintpoint yang memberikan informasi mengenai nama kabupaten yang bersangkutan dengan jenis produksinya, jumlah produksi dan tahun produksinya. Dan dibawah gambar web tersebut akan muncul tabel yang berisi informasi mengenai jenis produksi makanan dan minuman yang dihasilkan oleh kabupaten tersebut beserta jumlah produksi dan tahun produksinya.

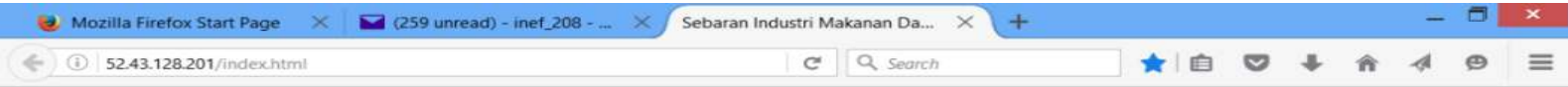

\section{SEBARAN INDUSTRI MAKANAN DAN MINUMAN DI INDONESIA}

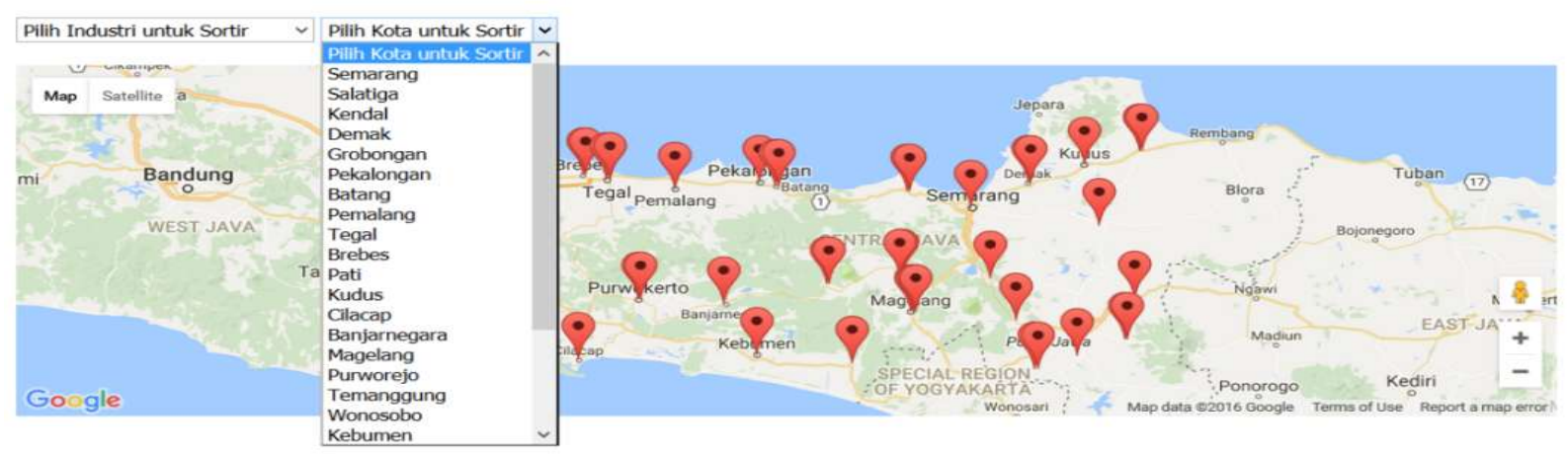

(2)

Gambar 4. Tampilan Informasi Pilih Kota Sortir.

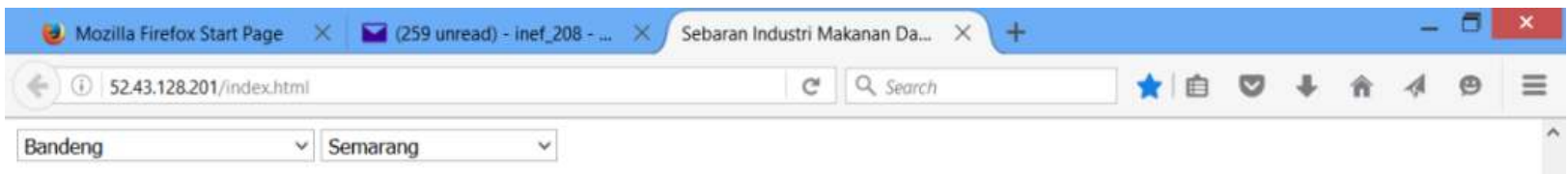

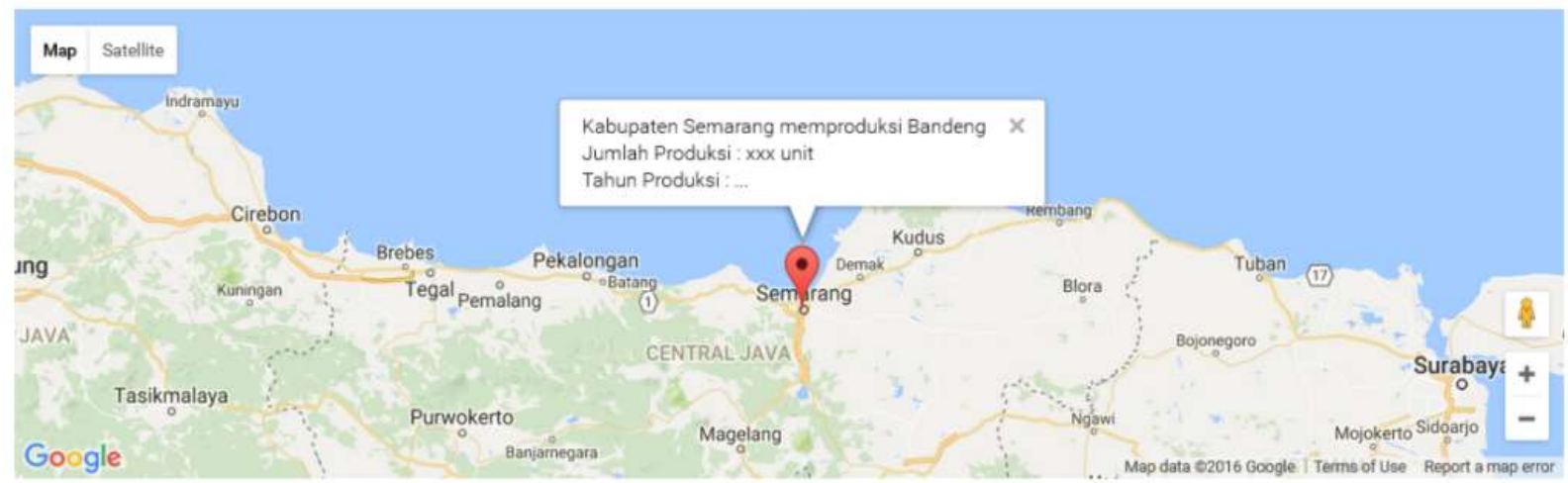

Hasil Industri Kota Semarang

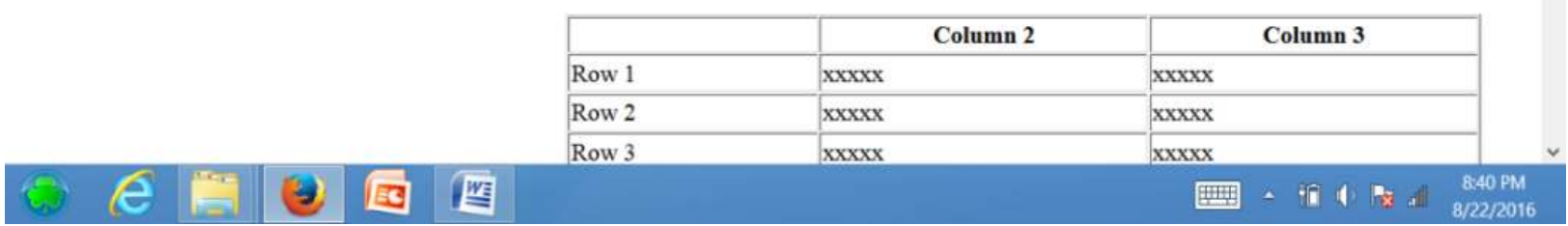

Gambar 5. Tampilan Informasi Pilih Industri dan Kota. 
Tampilan kelima pada gambar 6 apabila kita pilih sorot / highlight salah satu kota, maka akan muncul tampilan pintpoint yang memberikan informasi mengenai nama kabupaten yang bersangkutan dengan jenis produksinya, jumlah produksi dan tahun produksinya. Dan dibawah gambar web tersebut akan muncul tabel yang berisi informasi mengenai jenis produksi makanan dan minuman yang dihasilkan oleh Kabupaten tersebut beserta jumlah produksi dan tahun produksinya.

Tampilan keenam pada gambar 7, apabila kita sorot / highlight salah satu pinpoit, tanpa memilih tabel Pilih Industri untuk sortir dan pilih kota untuk Sortir, maka akan muncul tampilan yang memberikan informasi mengenai nama kabupaten yang bersangkutan dengan jenis produksinya, jumlah produksi dan tahun produksinya. Dan dibawah gambar web tersebut akan muncul tabel yang berisi informasi mengenai jenis produksi makanan dan minuman yang dihasilkan oleh Kabupaten tersebut beserta jumlah produksi dan tahun produksinya.

Secara keseluruhan tahapan perancangan web industri pengolahan pangan unggulan sudah dibuat dengan melakukan tiga kali perbaikan perancangan. Di harapkan rancangan ini menjadi rujukan awal penelusuran informasi keberadaan industri pengolahan pangan unggulan di semua daerah di Indonesia. Peneliti mengupayakan kelengkapan sumber data dan informasi secara terus menerus tentang keberadaan industri unggulan di masing - masing daerah di Indonesia.

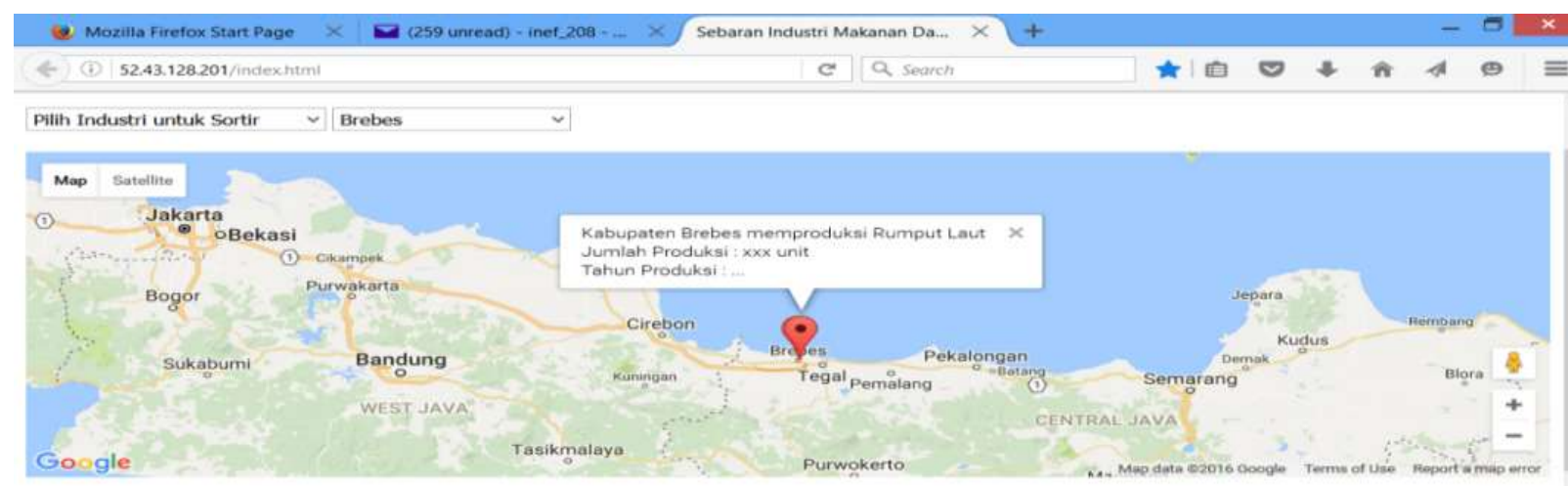

Hasil Industri Kota Brebes

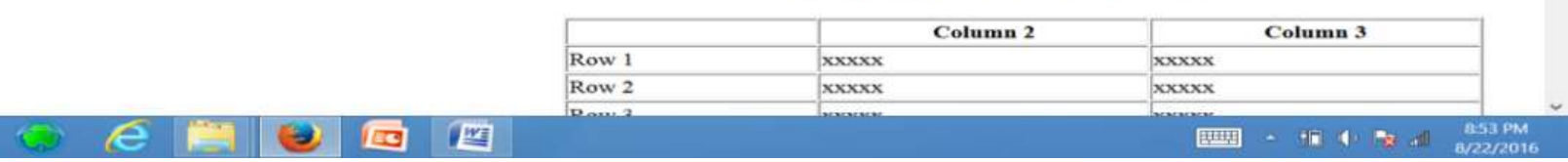

Gambar 6. Tampilan Informasi Pilih Kota.

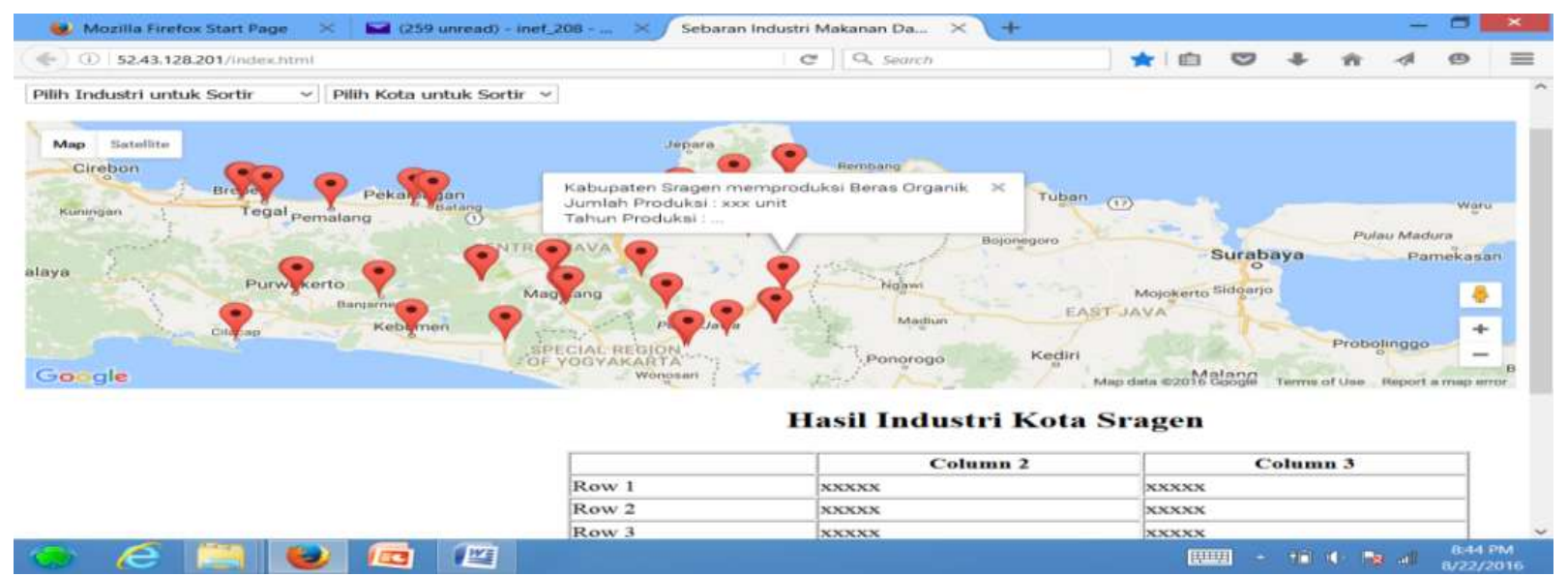

Gambar 7. Tampilan Informasi Pilih Salah Satu Pinpoint. 


\section{KESIMPULAN}

Industri pengolahan pangan unggulan terus ditingkatkan oleh pemerintah, terutama di seluruh daerah yang memiliki dan mampu menggali komoditas unggulannya. Sekaligus peningkatan kesejahteraan petani diperlukan kebijakan jangka panjang dan jangka pendek seperti diperlukan kebijakan perlindungan petani dengan pembatasan impor namun hendaknya didukung pula dengan kebijakan yang mendorong peningkatan produksi domestik melalui upaya peningkatan produktivitas industri pengolahan pangan unggulan seperti di pulau Jawa, Sumatera dan Sulawesi.

Penelitian ini merancang prototype sistem informasi geografis guna melakukan pemetaan yang lebih akurat untuk mengetahui industri pengolahan pangan unggulan lokal di Indonesia. Tahapan yang dilakukan adalah mendokumentasikan dan memetakan hasil industri pengolahan yang merupakan produk lokal unggulan. Pendokumentasian ini memerlukan pemanfaatan berbagai potensi fisik, ekonomi, lingkungan dan sosial budaya yang dimiliki dengan pemanfaatan teknologi informasi dan komunikasi yang memiliki kemampuan accesability dan relevancy informasi yang handal.

\section{DAFTAR PUSTAKA}

Budiyanto, E., 2002. Sistem Informasi Geografis Menggunakan ARCVIEW GIS. Penerbit Andi. Yogyakarta.

Badan Ketahanan Pangan Kementerian Pertanian Republik Indonesia, 2012. Roadmap Diversifikasi Pangan Tahun 2011-2015. Penerbit Kementerian Pertanian Republik Indonesia.

Mao, J, R. Dutton, W. Chen and W. Watson, 2008. Parallel Job Scheduling with Overhead: A Benchmark Study. Proceedings of the IEEE International Conference on Networks, Architecture, and Storage (NAS), pp. 326-333.

Prahasta, E., 2005. Konsep - konsep Dasar Sistem Informasi Geografis, Informatika Bandung.

Prahasta, E. 2007. Membangun Aplikasi Web-Based GIS dengan MapServer (Vol.1). Bandung: Informatika Bandung.

Teddy Oswari, Fenni Agustina, Emy Haryatmi, E. Susy Suhendra, 2013. Development of Crops Featured Commodities Application in Java and Sumatera Island Based on Geographic Information System. International Journal of Advanced Agricultural Sciences and Technology. Volume 2, Issue 1, pp. 45-52.

Z. Duran A, A. Garagon Doğru B, G. Toz, 2003. Web-Based Multimedia GIS for Historical Sites as in: International Symposium CIPA, Turkey. 